$\underline{\text { SUPPORTING INFORMATION }}$

\title{
Carbon-Carbon Bond Formation in the Surprising Rearrangement of Diorganylzirconium Dialkoxides: Linear Dimerization of Terminal Olefins ${ }^{1}$
}

\author{
John J. Eisch* and Somnath Dutta \\ Department of Chemistry, P.O. Box 6000 \\ The State University of New York at Binghamton \\ Binghamton, New York 13902-6000 \\ Fax: 607-777-4865 \\ jjeisch@binghamton.edu
}

\section{EXPERIMENTAL SECTION}

\section{A. General Procedures}

All processes involving purification of reaction solvents, distillation of reagents, generation of alkylzirconium halides or ethoxides and their subsequent reactions with organic substrates were performed under a positive pressure of anhydrous, deoxygenated argon. The drying and deoxygenation of both the argon and any solvents (tetrahydrofuran, hexane, toluene, diethyl ether, 2-methoxyethyl ether, benzene and octane) used in the reactions were carried out using established literature procedures. ${ }^{1}$

The solid commercial reagents were used as received while commercially purchased liquid reagents were distilled freshly under argon prior to reaction. Where distillation was not feasible, they were dried over $4 \mathrm{~A}^{\circ}$ Molecular Sieves (previously dried at $120^{\circ} \mathrm{C}$ ) and saturated with argon immediately before use. Commercially purchased anhydrous, solid reagents such as $\mathrm{Zr}(\mathrm{OEt})_{4}$ and $\mathrm{ZrCl}_{4}$ were purchased from Aldrich (at least $97 \%$ pure) and were stored under dry argon. The alkyllithium reagents and alkyl Grignard reagents were used as received in Aldrich Sure Seal ${ }^{\mathrm{TM}}$ bottles and their Sure Seal ${ }^{\mathrm{TM}}$ was reinforced with fresh wax after every use. 
Glassware and needles used to transfer liquid samples were dried in an oven at $120^{\circ} \mathrm{C}$ overnight to ensure complete absence of moisture and needles were thoroughly flushed with argon before every use.

The standard hydrolytic work-up procedure was as follows. The reaction mixture was treated with distilled water or deuteriated water at room temperature or with methanol at the low temperature of $-78^{\circ} \mathrm{C}$. The organic layer containing the desired products was extracted three times with $20 \mathrm{~mL}$ of anhydrous diethyl ether. The combined organic extracts were washed with $20 \mathrm{~mL}$ of water and dried over solid anhydrous $\mathrm{Na}_{2} \mathrm{SO}_{4}$ and filtered, after which solvent was removed at the rotary film evaporator.

\section{B. Instrumentation}

All melting points were determined by a Thomas-Hoover capillary melting point apparatus and are uncorrected. Infrared spectra (IR) were recorded using Perkin-Elmer spectrophotometers, Model 457 and 283B, equipped with sodium chloride optics, and samples were measured either as mineral oil mulls or $\mathrm{KBr}$ films. Nuclear magnetic resonance (NMR) spectra $\left({ }^{1} \mathrm{H}\right.$ and ${ }^{13} \mathrm{C}$ NMR $)$ were obtained in deuteriated solvents with Bruker spectrometers, Model AM-360 and AC-300. The ${ }^{1} \mathrm{H}$ NMR data are reported in parts per million (ppm) on the $\delta$ scale relative to internal standard tetramethylsilane (TMS) or to deuteriated solvents as references. The ${ }^{13} \mathrm{C}$ NMR data are reported in ppm on the $\delta$ scale with deuteriated chloroform $\left(\mathrm{CDCl}_{3}\right)$ as the reference. The GC/MS measurements and analyses were performed with a Hewlett-Packerd GC 5890/Hewlett-Packard 5970 mass-selective-detector instrument. The gas chromatographic analyses were carried out with a Hewlett-Packard instrument (model 5880) 
provided with a 2-m OV-101 packed column or with a Hewlett-Packard instrument (model 4890) having a $30 \mathrm{~m}$ SE-30 capillary column.

Thin layer chromatographic (TLC) analyses were carried out with EM Science chromatogram sheets, silica gel $60 \mathrm{~F}_{254}$. Silica gel (Grade 62, 60-200 mesh) was used for the column chromatographic separations, with a hexane-ethylacetate gradient for elution.

\section{General Preparations and Reactions of the Diorganylzirconium(IV) Derivatives}

\section{Run 1. (run number according to Table 1)}

\section{Preparation of $\mathrm{Bu}_{2} \mathrm{Zr}(\mathrm{OEt})_{2}$ in hexane at low temperature}

To a white suspension of $\mathrm{Zr}(\mathrm{OEt})_{4}(0.53 \mathrm{~g}, 1.95 \mathrm{mmol})$ in hexane $(35 \mathrm{~mL})$ cooled to $-78^{\circ} \mathrm{C}$ (Dry Ice-acetone bath) was slowly added $n$-BuLi $(2.5 \mathrm{M}$ in hexane, $1.5 \mathrm{~mL}, 3.9 \mathrm{mmol})$, whereupon the solution turned to an off-white color on standing at low temperature for $2 \mathrm{~h}$ to give rise to $\mathrm{Bu}_{2} \mathrm{Zr}(\mathrm{OEt})_{2}(1.95 \mathrm{mmol})$ in hexane, containing LiOEt as by-product.

\section{The reaction of $\mathrm{Bu}_{2} \mathrm{Zr}(\mathrm{OEt})_{2}$ containing LiOEt in hexane at reflux}

A suspension of $\mathrm{Bu}_{2} \mathrm{Zr}(\mathrm{OEt})_{2}(1.95 \mathrm{mmol})$ containing LiOEt in hexane was allowed to warm to room temperature in $2 \mathrm{~h}$ and stirred at room temperature for $2 \mathrm{~h}$ whereupon the color turned chocolate brown. Thereafter it was heated at reflux for $8 \mathrm{~h}$ when the solution became deep brown before being subjected to hydrolysis by water (after removing a portion of the reaction mixture for deuteriolysis by $\left.\mathrm{D}_{2} \mathrm{O}\right)$. Upon hydrolysis considerable amount of gas evolution $\left(\mathrm{H}_{2}\right)$ was noticed. The organics were extracted into diethyl ether and dried over anhydrous $\mathrm{Na}_{2} \mathrm{SO}_{4}$. The extracts were freed of solvent by using a rotary evaporator to result in the isolation of $110 \mathrm{mg}$ of a colorless liquid containing $50 \%$ octane (expected yield $222 \mathrm{mg}$ ) based on the ${ }^{1} \mathrm{H}$ and ${ }^{13} \mathrm{C}$ NMR analysis of the residue. The experimental yield of octane was determined by the addition 
of a known aliquot of $\mathrm{p}$-xylene $(0.10 \mathrm{~mL}, 0.886 \mathrm{mmol})$ to the residue and the calculation of observed yield of octane by comparing ${ }^{1} \mathrm{H}$ NMR integration values for p-xylene $\left(2 \mathrm{CH}_{3}\right)$ at 2.27ppm (1.0) and octane $\left(2 \mathrm{CH}_{3}\right)$ at $0.88 \mathrm{ppm}$ (1.1). Octane was characterized by TLC and distinguished from hexane by spiking the sample with hexane, whereafter a characteristic hexane peak was noticed in the ${ }^{13} \mathrm{C}$ NMR at $32.3 \mathrm{ppm}$.

Octane

${ }^{1} \mathrm{H}$ NMR $\left(\mathrm{CDCl}_{3}\right)$ \&: $1.26\left(\mathrm{br}, 12 \mathrm{H}, 6 \mathrm{CH}_{2}\right), 0.88\left(\mathrm{br}, 6 \mathrm{H}, 2 \mathrm{CH}_{3}\right)$;

${ }^{13} \mathrm{C} \mathrm{NMR}\left(\mathrm{CDCl}_{3}\right)$ \&: $32.05\left(\mathrm{C}_{3}\right), 29.45\left(\mathrm{C}_{4} \& \mathrm{C}_{5}\right), 22.78\left(\mathrm{C}_{2} \& \mathrm{C}_{7}\right), 14.09\left(\mathrm{C}_{1} \& \mathrm{C}_{8}\right)$.

Hexane

${ }^{1} \mathrm{H} \mathrm{NMR}\left(\mathrm{CDCl}_{3}\right) \delta: 1.27\left(\mathrm{br}, 8 \mathrm{H}, 4 \mathrm{CH}_{2}\right), 0.91\left(\mathrm{br}, 6 \mathrm{H}, 2 \mathrm{CH}_{3}\right)$;

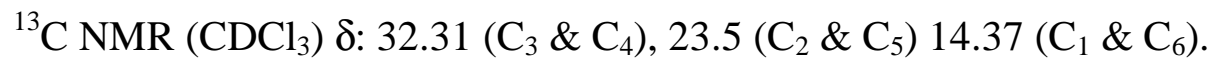

The deuteriolytic work-up of a portion of the reaction mixture by $\mathrm{D}_{2} \mathrm{O}$ yielded 4-deuteriooctane as corroborated by the ${ }^{2} \mathrm{H}$ NMR analysis of the residue.

${ }^{2} \mathrm{H}$ NMR $\left(\mathrm{CH}_{3} \mathrm{COOD}\right) \delta: 1.33\left(\mathrm{CH}_{3} \mathrm{CH}_{2} \mathrm{CH}_{2} \mathrm{CH}_{2} \mathrm{CHDCH}_{2} \mathrm{CH}_{2} \mathrm{CH}_{3}\right)$.

\section{$\underline{\text { Run } 2}$}

\section{Preparation of $\mathrm{Bn}_{2} \mathrm{Zr}(\mathrm{OEt})_{2}$ in THF at low temperature}

To a white suspension of $\mathrm{Zr}(\mathrm{OEt})_{4}(0.79 \mathrm{~g}, 2.91 \mathrm{mmol})$ in $\mathrm{THF}(35 \mathrm{~mL})$ cooled to $-78^{\circ} \mathrm{C}$ (Dry Ice-acetone bath) was slowly added $\mathrm{BnMgCl}(2.0 \mathrm{M}$ in $\mathrm{THF}, 2.9 \mathrm{~mL}, 5.82 \mathrm{mmol})$ whereupon the solution turned pale yellow color on standing at low temperature for $2 \mathrm{~h}$ to give rise to $\mathrm{Bn}_{2} \mathrm{Zr}(\mathrm{OEt})_{2}(2.91 \mathrm{mmol})$, containing $\mathrm{MgCl}(\mathrm{OEt})$ as by-product. 


\section{The reaction of $\mathrm{Bn}_{2} \mathrm{Zr}(\mathrm{OEt})_{2}$ in $\mathrm{THF}$ at reflux}

A suspension of $\mathrm{Bn}_{2} \mathrm{Zr}(\mathrm{OEt})_{2}(2.91 \mathrm{mmol})$ in THF was allowed to warm to room temperature in $2 \mathrm{~h}$, stirred at room temperature for $2 \mathrm{~h}$ and thereafter heated for $8 \mathrm{~h}$ at reflux whereupon the solution turned brown before hydrolysis (after removing a portion of the reaction mixture for deuteriolysis by $\left.\mathrm{D}_{2} \mathrm{O}\right)$. Upon hydrolysis considerable gas evolution $\left(\mathrm{H}_{2}\right)$ was noticed. The organics were extracted with diethyl ether and dried over anhydrous $\mathrm{Na}_{2} \mathrm{SO}_{4}$. The extracts were freed of solvent to result in the isolation of $420 \mathrm{mg}$ of a pasty yellow solid consisting of 79\% bibenzyl, (expected yield 530mg), [ $\left.\delta_{\mathrm{H}}: 2.91\left(\mathrm{~s}, \mathrm{CH}_{2} \mathrm{CH}_{2}\right) ; \delta_{\mathrm{C}}: 37.95\left(\mathrm{CH}_{2}\right)\right]$. Other products from this reaction were $17 \%$ toluene $\left[\delta_{\mathrm{H}}: 2.3\left(\mathrm{~s}, \mathrm{CH}_{3}\right) ; \delta_{\mathrm{C}}: 21.5\left(\mathrm{CH}_{3}\right)\right], 2 \% \mathrm{t}-$ stilbene $\left[\delta_{\mathrm{H}}: 7.1(\mathrm{~s},=\mathrm{CH})\right]$ and $2 \%$ of benzyl alcohol $\left[\delta_{\mathrm{H}}: 4.7\left(\mathrm{~d}, \mathrm{CH}_{2}\right) ; \delta_{\mathrm{C}}: 65.2\left(\mathrm{CH}_{2}\right)\right]$ based on the ${ }^{1} \mathrm{H}$ and ${ }^{13} \mathrm{C}$ NMR analyses of the residue.

Bibenzyl

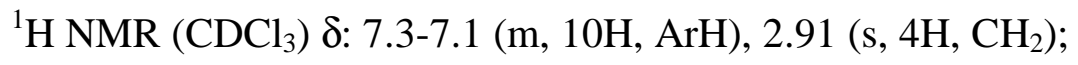

${ }^{13} \mathrm{C} \mathrm{NMR}\left(\mathrm{CDCl}_{3}\right) \delta: 141.79,128.9,125.92(\mathrm{ArC}), 37.95\left(\mathrm{CH}_{2}\right)$.

Toluene

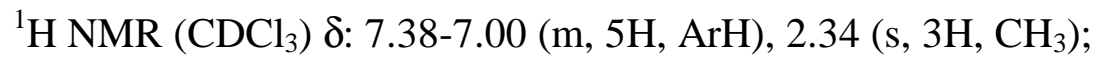

${ }^{13} \mathrm{C} \mathrm{NMR}\left(\mathrm{CDCl}_{3}\right) \delta: 137.83,129.29,128.48,125.38(\mathrm{ArC}), 21.41\left(\mathrm{CH}_{3}\right)$.

t-Stilbene

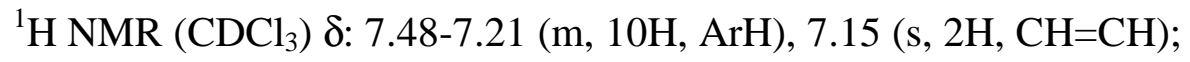

${ }^{13} \mathrm{C} \mathrm{NMR}\left(\mathrm{CDCl}_{3}\right) \delta:$ 137.36, 128.67, 127.61, $126.53(\mathrm{ArC}), 128.67(\mathrm{C}=\mathrm{C})$.

Benzyl alcohol

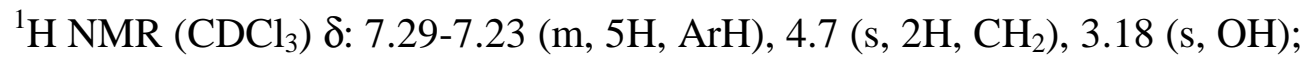

${ }^{13} \mathrm{C} \mathrm{NMR}\left(\mathrm{CDCl}_{3}\right) \delta: 140.91,128.38,127.39,126.95(\mathrm{ArC}), 65.2\left(\mathrm{CH}_{2} \mathrm{OH}\right)$. 
The deuteriolytic work-up of a portion of the reaction mixture by $\mathrm{D}_{2} \mathrm{O}$ yielded $\alpha$ monodeuteriated bibenzyl as detailed by ${ }^{2} \mathrm{H}$ NMR analysis of the residue.

${ }^{2} \mathrm{H}$ NMR $\left(\mathrm{CH}_{3} \mathrm{CN}\right) \delta: 2.8\left(\mathrm{PhCH}_{2} \mathrm{CHDPh}\right)$.

The $\alpha$-monodeuteriobibenzyl was isolated by flash column chromatography using hexane-ethylacetate gradient (10:1) for elution and a silica gel column (grade 62, 60-200 mesh) and characterized by its ${ }^{1} \mathrm{H}$ NMR analysis. Integration of the aromatic proton signals at 7.1-7.3 ppm and benzylic proton signals at $2.9 \mathrm{ppm}$ produced an observed ratio of 10.0: 3.13, compared with an expected ratio of 10.0: 3.0 for pure $\alpha$-monodeuteriobibenzyl, thus indicating an isotopic purity of at least $87 \%$ of $\alpha$-deuteriation. The monodeuteriated and undeuteriated benzylic carbons were identified by separate absorption peaks in the ${ }^{13} \mathrm{C}$ NMR of the sample and characterized further by a DEPT experiment.

To test for any photolytic behavior of $\mathrm{Bn}_{2} \mathrm{Zr}(\mathrm{OEt})_{2}$, this reaction was repeated in the dark when $68 \%$ bibenzyl was obtained, which certainly rules out any major participation of light in the reaction.

\section{Preparation of $\mathrm{Bn}_{2} \mathrm{ZrCl}_{2}$ in THF at low temperature}

To a white suspension of $\mathrm{ZrCl}_{4}(1.08 \mathrm{~g}, 4.6 \mathrm{mmol})$ in $\mathrm{THF}(35 \mathrm{~mL})$ cooled to $-78^{\circ} \mathrm{C}$ (Dry Ice-acetone bath) were slowly added $\mathrm{BnMgCl}(2.0 \mathrm{M}$ in THF, $4.6 \mathrm{~mL}, 9.2 \mathrm{mmol})$ whereupon the solution turned pale yellow color on standing at low temperature for $2 \mathrm{~h}$, to give rise to $\mathrm{Bn}_{2} \mathrm{ZrCl}_{2}$ (4.6mmol), containing $\mathrm{MgCl}(\mathrm{OEt})$ by-product.

\section{The reaction of $\mathrm{Bn}_{2} \mathrm{ZrCl}_{2}$ in $\mathrm{THF}$ at reflux}

A suspension of $\mathrm{Bn}_{2} \mathrm{ZrCl}_{2}$ (4.6mmol) in $\mathrm{THF}$ was allowed to warm to room temperature in $2 \mathrm{~h}$ and stirred at room temperature for $2 \mathrm{~h}$ and thereafter heated for $8 \mathrm{~h}$ at reflux when the solution turned brown before being subjecting to hydrolysis (after removing a portion of the 
reaction mixture for deuteriolysis by $\left.\mathrm{D}_{2} \mathrm{O}\right)$. Upon hydrolysis considerable gas $\left(\mathrm{H}_{2}\right)$ evolution was noticed. The organics were extracted with diethyl ether and dried over anhydrous $\mathrm{Na}_{2} \mathrm{SO}_{4}$. The extracts were freed of solvent to result in the isolation of $360 \mathrm{mg}$ pasty yellow solid consisting of $44 \%$ bibenzyl (expected yield $838 \mathrm{mg}$ ) and $56 \%$ toluene, based on the ${ }^{1} \mathrm{H}$ and ${ }^{13} \mathrm{C}$ NMR analysis of the residue.

The deuteriolytic work-up of a portion of the reaction mixture by $\mathrm{D}_{2} \mathrm{O}$ yielded $\alpha$ monodeuteriated bibenzyl, as revealed by the ${ }^{2} \mathrm{H}$ NMR analysis of the residue.

${ }^{2} \mathrm{H}$ NMR $\left(\mathrm{CH}_{3} \mathrm{CN}\right) \delta: 2.8\left(\mathrm{PhCH}_{2} \mathrm{CHDPh}\right)$.

\section{$\underline{\operatorname{Run} 3}$}

\section{Preparation of $\mathrm{BnZr}(\mathrm{OEt})_{3}$ in THF at low temperature}

To a white suspension of $\mathrm{Zr}(\mathrm{OEt})_{4}(0.49 \mathrm{~g}, 1.80 \mathrm{mmol})$ in $\mathrm{THF}(35 \mathrm{~mL})$ cooled to $-78^{\circ} \mathrm{C}$ (Dry Ice-acetone bath) was slowly added $\mathrm{BnMgCl}(2.0 \mathrm{M}$ in THF, $0.9 \mathrm{~mL}, 1.80 \mathrm{mmol})$ whereupon the solution turned pale yellow color on standing at low temperature for $2 \mathrm{~h}$, to give rise to $\mathrm{BnZr}(\mathrm{OEt})_{3}(1.80 \mathrm{mmol})$, containing $\mathrm{MgCl}(\mathrm{OEt})$ a by-product.

\section{The reaction of $\mathrm{BnZr}(\mathrm{OEt})_{3}$ in $\mathrm{THF}$ at reflux}

A suspension of $\mathrm{BnZr}(\mathrm{OEt})_{3}(1.80 \mathrm{mmol})$ in $\mathrm{THF}$ was allowed to warm to room temperature in $2 \mathrm{~h}$ and stirred at room temperature for $2 \mathrm{~h}$ and thereafter was heated for $8 \mathrm{~h}$ at reflux when the solution turned brown before hydrolysis. Upon hydrolysis no gas evolution was noticed. The organics were extracted with diethyl ether and dried over anhydrous $\mathrm{Na}_{2} \mathrm{SO}_{4}$. The extracts were freed of solvent by using a rotary evaporator to result in isolation of $153 \mathrm{mg}$ of a yellow liquid consisting of pure toluene with a trace of t-stilbene (confirmed by TLC

experiment) but no bibenzyl, based on the ${ }^{1} \mathrm{H}$ and ${ }^{13} \mathrm{C}$ NMR analysis of the residue. Absence of 
any peak at $4.47 \mathrm{ppm}$ and $3.21 \mathrm{ppm}$ in the ${ }^{1} \mathrm{H}$ NMR spectrum is confirmation of the absence of any intramolecular rearrangement to form benzyl ethyl ether.

\section{$\underline{\operatorname{Run} 4}$}

\section{Preparation of $\left(\mathrm{PhCH}_{2} \mathrm{CH}_{2}\right)_{2} \mathrm{Zr}(\mathrm{OEt})_{2}$ in THF at low temperature}

To finely divided magnesium turnings $(0.1 \mathrm{~g}, 4.1 \mathrm{mmol})$ in $20 \mathrm{~mL}$ THF was slowly added $\mathrm{PhCH}_{2} \mathrm{CH}_{2} \mathrm{Br}(0.73 \mathrm{~mL}, 4 \mathrm{mmol})$ and thereafter the resulting yellow solution was heated at reflux for $12 \mathrm{~h}$. After cooling the reaction mixture to room temperature, the clear solution excluding any unreacted magnesium, was carefully transferred to a white suspension of $\mathrm{Zr}(\mathrm{OEt})_{4}(0.54 \mathrm{~g}$, $2 \mathrm{mmol}$ ) in THF (20mL) cooled to $-78^{\circ} \mathrm{C}$ (Dry Ice-acetone bath), whereupon the solution turned grayish white color on standing at low temperature for $2 \mathrm{~h}$, to give rise to $\left(\mathrm{PhCH}_{2} \mathrm{CH}_{2}\right)_{2} \mathrm{Zr}(\mathrm{OEt})_{2}$ (2mmol), containing $\mathrm{MgBr}(\mathrm{OEt})$ as by-product.

\section{The reaction of $\left(\mathrm{PhCH}_{2} \mathrm{CH}_{2}\right)_{2} \mathrm{Zr}(\mathrm{OEt})_{2}$ in THF at reflux}

A suspension of $\left(\mathrm{PhCH}_{2} \mathrm{CH}_{2}\right)_{2} \mathrm{Zr}(\mathrm{OEt})_{2}(2 \mathrm{mmol})$ in $\mathrm{THF}$ was allowed to warm to room temperature in $2 \mathrm{~h}$ and stirred at room temperature for $2 \mathrm{~h}$, followed by $8 \mathrm{~h}$ reflux, when the color changed to light brown before being subjecting to hydrolysis. Upon hydrolysis little gas evolution was noticed. The organics were extracted with diethyl ether and dried over anhydrous $\mathrm{Na}_{2} \mathrm{SO}_{4}$. The extracts were freed of solvent by using a rotary evaporator to result in isolation of 92mg of a pasty yellow liquid consisting of 22\% 1,4-diphenylbutane, (expected yield 420mg), [ $\left.\delta_{\mathrm{H}}: 1.65\left(\mathrm{~m}, 4 \mathrm{H}, 2 \mathrm{CH}_{2}\right), 2.62\left(\mathrm{~m}, 4 \mathrm{H}, 2 \mathrm{CH}_{2}\right) ; \delta_{\mathrm{C}}: 34.8\left(2 \mathrm{CH}_{2}\right), 31.03\left(2 \mathrm{CH}_{2}\right)\right]$. Other products in this reaction are $7 \%$ propylbenzene $\left[\delta_{\mathrm{H}}: 2.49\left(\mathrm{t}, 2 \mathrm{H}, \mathrm{CH}_{2}\right), 2.0-1.8\left(\mathrm{~m}, 2 \mathrm{H}, \mathrm{CH}_{2}\right), 0.9(\mathrm{t}, 3 \mathrm{H}\right.$, $\left.\left.\mathrm{CH}_{3}\right) ; \delta_{\mathrm{C}}: 23.65\left(\mathrm{CH}_{2}\right)\right], 6 \%$ toluene $\left[\delta_{\mathrm{H}}: 2.3\left(\mathrm{~s}, 3 \mathrm{H}, \mathrm{CH}_{3}\right) ; \delta_{\mathrm{C}}: 21.4\left(\mathrm{CH}_{3}\right)\right]$, and $65 \%$ ethylbenzene based on the ${ }^{1} \mathrm{H}$ and ${ }^{13} \mathrm{C}$ NMR analysis of the residue. 
1,4-Diphenylbutane

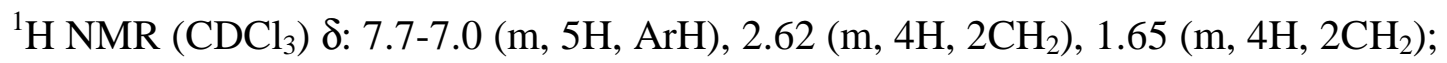

${ }^{13} \mathrm{C} \mathrm{NMR}\left(\mathrm{CDCl}_{3}\right) \delta: 142.48,128.28,127.83,125.60(\mathrm{ArC}), 34.8\left(2 \mathrm{CH}_{2}\right), 31.03\left(2 \mathrm{CH}_{2}\right)$.

Propylbenzene

${ }^{1} \mathrm{H}$ NMR $\left(\mathrm{CDCl}_{3}\right)$ \&: 7.4-7.0 (m, 5H, ArH), $2.49\left(\mathrm{t}, 2 \mathrm{H}, \mathrm{CH}_{2}\right), 2.0-1.8\left(\mathrm{~m}, 2 \mathrm{H}, \mathrm{CH}_{2}\right), 0.9(\mathrm{t}, 3 \mathrm{H}$, $\left.\mathrm{CH}_{3}\right)$;

${ }^{13} \mathrm{C} \mathrm{NMR}\left(\mathrm{CDCl}_{3}\right) \delta: 143.67,128.51,128.26,125.67(\mathrm{ArC}), 38.09\left(\mathrm{CH}_{2}\right), 23.65\left(\mathrm{CH}_{2}\right), 14.1$ $\left(\mathrm{CH}_{3}\right)$.

Toluene

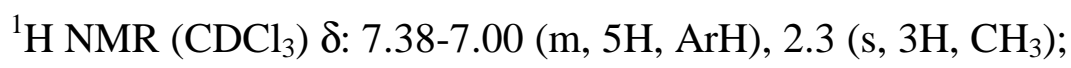

${ }^{13} \mathrm{C}$ NMR $\left(\mathrm{CDCl}_{3}\right) \delta: 137.83,129.29,128.48,125.38(\mathrm{ArC}), 21.41\left(\mathrm{CH}_{3}\right)$.

Ethylbenzene

${ }^{1} \mathrm{H} \mathrm{NMR}\left(\mathrm{CDCl}_{3}\right)$ 8: 7.45-7.0 (m, 5H, $\left.\mathrm{ArH}\right), 2.63\left(\mathrm{q}, 2 \mathrm{H}, \mathrm{CH}_{2}\right), 1.22\left(\mathrm{t}, 3 \mathrm{H}, \mathrm{CH}_{3}\right)$;

${ }^{13} \mathrm{C} \mathrm{NMR}\left(\mathrm{CDCl}_{3}\right) \delta: 144.24,128.35,127.89,125.65(\mathrm{ArC}), 28.9\left(\mathrm{CH}_{2}\right), 15.6\left(\mathrm{CH}_{3}\right)$.

\section{$\underline{\text { Run } 5}$}

The reaction of 1 equivalent of $B u_{2} \operatorname{Zr}(\mathrm{OEt})_{2}$ containing LiOEt with two molar equivalents of $\mathrm{Ph}_{2} \mathrm{CH}_{2}$ in THF at reflux

A suspension of $\mathrm{Bu}_{2} \mathrm{Zr}(\mathrm{OEt})_{2}(1.39 \mathrm{mmol})$ containing LiOEt in THF was allowed to react with $0.46 \mathrm{~mL}$ ( 2 equiv.) of freshly distilled diphenylmethane in $\operatorname{THF}(35 \mathrm{~mL})$ at $-78^{\circ} \mathrm{C}$ causing the color of the suspension to turn yellow. The resulting mixture was allowed to warm to room temperature over $2 \mathrm{~h}$ during which moderate gas evolution was noticed. The suspension was stirred at room temperature for $2 \mathrm{~h}$ during which the suspension turned orange. An 8-h reflux 
period was conducted during which further gas evolution was noticed and the solution turned brown. The mixture was hydrolyzed after removing a portion of the reaction mixture for deuteriolysis by $\mathrm{D}_{2} \mathrm{O}$. Upon hydrolysis considerable amount of gas evolution was noticed, identified to be hydrogen by mass spectrometry and its lack of reaction on passing through a solution of $\mathrm{Br}_{2}$ in $\mathrm{CCl}_{4}$. The organics were extracted with diethyl ether and dried over anhydrous $\mathrm{Na}_{2} \mathrm{SO}_{4}$. The extracts were freed of solvent by using a rotary evaporator to result in the isolation of $441 \mathrm{mg}$ of pasty yellow liquid consisting of $74 \%$ tetraphenylethylene [ $\left.\delta_{\mathrm{H}}: 7.06(\mathrm{~s}, 20 \mathrm{H}, \mathrm{ArH})\right]$ and $26 \%$ diphenylmethane based on the ${ }^{1} \mathrm{H}$ and ${ }^{13} \mathrm{C}$ NMR analysis of the residue.

Tetraphenylethylene $\left(\mathrm{Ph}_{2} \mathrm{C}=\mathrm{CPh}_{2}\right)$

${ }^{1} \mathrm{H}$ NMR $\left(\mathrm{CDCl}_{3}\right) \delta: 7.06(\mathrm{~m}, 20 \mathrm{H}, \mathrm{ArH})$;

${ }^{13} \mathrm{C} \mathrm{NMR}\left(\mathrm{CDCl}_{3}\right) \delta: 143.71,141.0,131.3,127.6,126.39(\mathrm{ArC}), 140.96(\mathrm{C}=\mathrm{C})$.

Diphenylmethane $\left(\mathrm{Ph}_{2} \mathrm{CH}_{2}\right)$

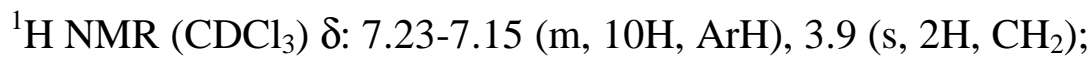

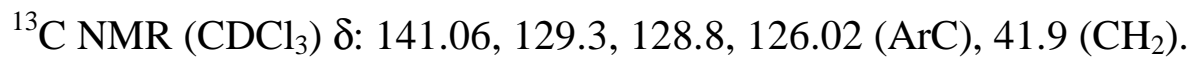

The deuteriolytic work-up of a portion of the reaction mixture by $\mathrm{D}_{2} \mathrm{O}$ yielded residual diphenylmethane, which consisted of $75 \%$ of $\alpha, \alpha$-dideuterio- $\left(\mathrm{Ph}_{2} \mathrm{CD}_{2}\right)$ and $25 \%$ of $\alpha$-monodeuterio- $\left(\mathrm{Ph}_{2} \mathrm{CHD}\right)$ diphenylmethane as detailed by ${ }^{2} \mathrm{H}$ and PENDANT ${ }^{13} \mathrm{C}$ NMR analysis of the residue. PENDANT ${ }^{13} \mathrm{C}$ NMR showed separate $\alpha-\mathrm{C}$ signals for $\mathrm{Ph}_{2} \mathrm{CD}_{2}$ and $\mathrm{Ph}_{2} \mathrm{CHD}$.

\section{$\underline{\text { Run } 6}$}

The reaction of 1 molar equivalent of $\mathrm{Bu}_{2} \mathrm{Zr}(\mathrm{OEt})_{2}$ containing LiOEt with 2 molar equivalents of 1,1-diphenylethane in THF at reflux 
A suspension of $\mathrm{Bu}_{2} \mathrm{Zr}(\mathrm{OEt})_{2}(0.59 \mathrm{mmol})$ containing LiOEt in THF was allowed to react with $0.21 \mathrm{~mL}$ ( 2 equiv.) of freshly distilled 1,1-diphenylethane in THF $(35 \mathrm{~mL})$ at $-78^{\circ} \mathrm{C}$ causing the color of the suspension to turn bright red. The resulting mixture was allowed to warm to room temperature in $2 \mathrm{~h}$ during which moderate gas evolution was noticed. Stirring the mixture at room temperature for $2 \mathrm{~h}$, followed by $8 \mathrm{~h}$ of reflux gave a brown suspension. After hydrolysis the organics were extracted with diethyl ether and dried over anhydrous $\mathrm{Na}_{2} \mathrm{SO}_{4}$. The extracts were freed of solvent to result in the isolation of $205 \mathrm{mg}$ of a yellow liquid containing only starting material as based on the ${ }^{1} \mathrm{H}$ and ${ }^{13} \mathrm{C}$ NMR analysis of the residue. No dimerization to 2,2,3,3-tetraphenylbutane was noticed since no signal at $1.5 \mathrm{ppm}$ for the methyl protons was observed in the proton NMR.

1,1-Diphenylethane

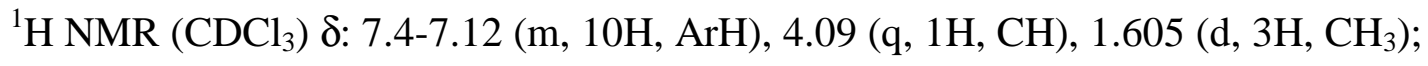

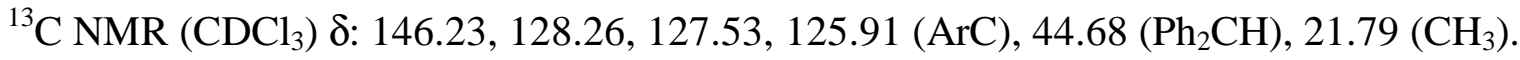
The reaction of 1 molar equivalent of $\mathrm{Bu}_{2} \mathrm{Zr}(\mathrm{OEt})_{2}$ containing LiOEt with 1 molar equivalent of 1,1-diphenylethane in THF at room temperature

A suspension of $\mathrm{Bu}_{2} \mathrm{Zr}(\mathrm{OEt})_{2}(1.65 \mathrm{mmol})$ containing LiOEt in THF was allowed to react with $0.29 \mathrm{~mL}$ ( 1 equiv.) of freshly distilled 1,1-diphenylethane in THF $(35 \mathrm{~mL})$ at $-78^{\circ} \mathrm{C}$ causing the color of the suspension to turn bright red. The resulting mixture was allowed to warm to room temperature in $2 \mathrm{~h}$ when moderate amount of gas evolution was noticed. It was stirred at room temperature for $72 \mathrm{~h}$ when the color of the suspension turned light brown, before being subjected to deuteriolysis by $\mathrm{D}_{2} \mathrm{O}$. The organics were dried over anhydrous $\mathrm{Na}_{2} \mathrm{SO}_{4}$. The extracts were freed of solvent to result in isolation of 280mg of a yellow liquid containing 1,1diphenylethane in its $\alpha$-deuterio form, as based on the ${ }^{1} \mathrm{H},{ }^{2} \mathrm{H}$ and ${ }^{13} \mathrm{C}$ NMR analysis of the 
residue. Absence of any benzylic proton in ${ }^{1} \mathrm{H}$ NMR of the residue confirms the absence of any $\mathrm{Ph}_{2} \mathrm{CHCH}_{3}$.

$\alpha$-Deuterio-1,1-diphenylethane

${ }^{1} \mathrm{H}$ NMR $\left(\mathrm{CDCl}_{3}\right) \delta: 7.4-7.12(\mathrm{~m}, 10 \mathrm{H}, \mathrm{ArH}), 1.58\left(\mathrm{~d}, 3 \mathrm{H}, \mathrm{CH}_{3}\right)$;

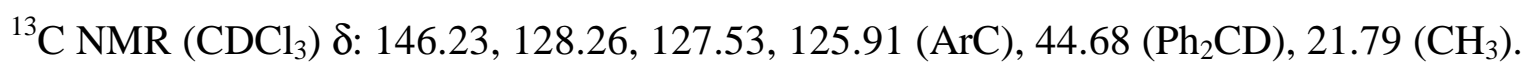

${ }^{2} \mathrm{H}$ NMR $\left(\mathrm{CDCl}_{3}\right) \delta: 4.03\left(\mathrm{Ph}_{2} \mathrm{CD}\right)$.

\section{$\underline{\text { Run } 7}$}

\section{Preparation of $\mathrm{Ph}(\mathrm{Bn}) \mathrm{Zr}(\mathrm{OEt})_{2}$ in THF at low temperature}

To a white suspension of $\mathrm{Zr}(\mathrm{OEt})_{4}(0.71 \mathrm{~g}, 2.61 \mathrm{mmol})$ in $\mathrm{THF}(35 \mathrm{~mL})$ cooled to $-78^{\circ} \mathrm{C}$ (Dry Ice-acetone bath) was slowly added first $\mathrm{BnMgCl}(2.0 \mathrm{M}$ in $\mathrm{THF}, 1.3 \mathrm{~mL}, 2.61 \mathrm{mmol})$ and then $\mathrm{PhMgCl}(2 \mathrm{M}$ in $\mathrm{THF}, 1.3 \mathrm{~mL}, 2.61 \mathrm{mmol})$, whereupon the solution turned to pale yellow color on standing at low temperature for $2 \mathrm{~h}$, to give rise to $\mathrm{PhBnZr}(\mathrm{OEt})_{2}(2.61 \mathrm{mmol})$, containing $\mathrm{MgCl}(\mathrm{OEt})$ as by-product.

\section{The reaction of $\mathrm{Ph}(\mathrm{Bn}) \mathrm{Zr}(\mathrm{OEt})_{2}$ in $\mathrm{THF}$ at reflux}

A suspension of $\mathrm{Ph}(\mathrm{Bn}) \mathrm{Zr}(\mathrm{OEt})_{2}(2.61 \mathrm{mmol})$ in $\mathrm{THF}$ was allowed to warm to room temperature in $2 \mathrm{~h}$ and stirred at room temperature for $2 \mathrm{~h}$ (when the color turned brown) and then was subjected to $8 \mathrm{~h}$ reflux during which the solution turned deep brown before subjecting to hydrolysis by water. Upon hydrolysis little gas evolution was noticed. The organics were extracted with diethyl ether and dried over anhydrous $\mathrm{Na}_{2} \mathrm{SO}_{4}$. The extracts were freed of solvent to result in the isolation of $127 \mathrm{mg}$ of pale yellow liquid consisting of $29 \%$ diphenylmethane (expected yield $439 \mathrm{mg})\left[\delta_{\mathrm{H}}: 3.9\left(\mathrm{~s}, 2 \mathrm{H}, \mathrm{CH}_{2}\right) ; \delta_{\mathrm{C}}: 41.9\left(\mathrm{CH}_{2}\right)\right]$. Other products from this 
reaction were $31 \%$ toluene and $40 \%$ benzene $[\delta: 7.33(\mathrm{~s}, 6 \mathrm{H}, \mathrm{ArH})]$, based on the ${ }^{1} \mathrm{H}$ and ${ }^{13} \mathrm{C}$ NMR analysis of the residue.

Diphenylmethane

${ }^{1} \mathrm{H}$ NMR $\left(\mathrm{CDCl}_{3}\right) \delta:$ 7.23-7.15 (m, 10H, $\left.\mathrm{ArH}\right), 3.9\left(\mathrm{~s}, 2 \mathrm{H}, \mathrm{CH}_{2}\right)$;

${ }^{13} \mathrm{C} \mathrm{NMR}\left(\mathrm{CDCl}_{3}\right) \delta: 141.06,129.3,128.8,126.02(\mathrm{ArC}), 41.9\left(\mathrm{CH}_{2}\right)$.

Toluene

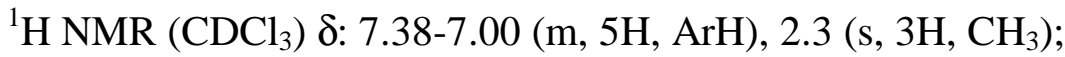

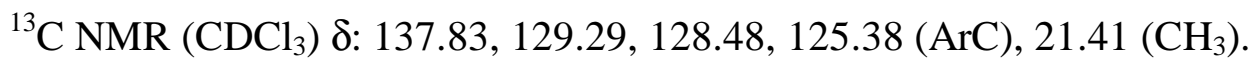

Benzene

${ }^{1} \mathrm{H} \mathrm{NMR}\left(\mathrm{CDCl}_{3}\right) \delta: 7.33(\mathrm{~s}, 6 \mathrm{H}, \mathrm{ArH})$.

${ }^{13} \mathrm{C} \mathrm{NMR}\left(\mathrm{CDCl}_{3}\right) \delta: 128.36(\mathrm{ArC})$.

\section{$\underline{\text { Run } 8}$}

\section{Preparation of $\left(\mathrm{PhCH}_{2} \mathrm{CH}_{2}\right)(\mathrm{Ph}) \mathrm{Zr}(\mathrm{OEt})_{2}$ in $\mathrm{THF}$ at low temperature}

To finely divided magnesium turnings $(0.05 \mathrm{~g}, 2 \mathrm{mmol})$ in $20 \mathrm{~mL}$ THF was slowly added $\mathrm{PhCH}_{2} \mathrm{CH}_{2} \mathrm{Br}(0.36 \mathrm{~mL}, 2 \mathrm{mmol})$ and the resulting pale yellow reaction mixture was then heated at reflux for $12 \mathrm{~h}$. After cooling the reaction mixture to room temperature, the clear solution (excluding any unreacted magnesium) was transferred to a white suspension of $\mathrm{Zr}(\mathrm{OEt})_{4}(0.54 \mathrm{~g}$, $2 \mathrm{mmol})$ in THF $(20 \mathrm{~mL})$ cooled to $-78^{\circ} \mathrm{C}$. Thereafter, to this suspension was slowly added $\mathrm{PhLi}$ (1.8M solution in diethyl ether, $1.1 \mathrm{~mL}, 2 \mathrm{mmol})$, whereupon the solution turned grayish on standing at low temperature for $2 \mathrm{~h}$, to give rise to $\left(\mathrm{PhCH}_{2} \mathrm{CH}_{2}\right) \mathrm{PhZr}(\mathrm{OEt})_{2}(2 \mathrm{mmol})$, containing $\operatorname{MgBr}(\mathrm{OEt})$ and LiOEt by-products. 


\section{The reaction of $\left(\mathrm{PhCH}_{2} \mathrm{CH}_{2}\right)(\mathrm{Ph}) \mathrm{Zr}(\mathrm{OEt})_{2}$ in $\mathrm{THF}$ at reflux}

A suspension of $\left(\mathrm{PhCH}_{2} \mathrm{CH}_{2}\right)(\mathrm{Ph}) \mathrm{Zr}(\mathrm{OEt})_{2}(2 \mathrm{mmol})$ in $\mathrm{THF}$ was allowed to warm to room temperature in $2 \mathrm{~h}$, stirred at room temperature for $2 \mathrm{~h}$ and then heated at reflux for $8 \mathrm{~h}$. Upon hydrolysis little gas evolution was noticed. The organics were extracted with diethyl ether and dried over anhydrous $\mathrm{Na}_{2} \mathrm{SO}_{4}$. The extracts were freed of solvent by using a rotary evaporator to result in isolation of $72 \mathrm{mg}$ of a pasty yellow solid containing $20 \%$ bibenzyl (expected yield $364 \mathrm{mg})\left[\delta_{\mathrm{H}}: 2.9\left(\mathrm{~s}, 4 \mathrm{H}, 2 \mathrm{CH}_{2}\right) ; \delta_{\mathrm{C}}: 37.9\left(\mathrm{CH}_{2}\right)\right]$. Other products in this reaction were $42 \%$ ethylbenzene $\left[\delta_{\mathrm{H}}: 2.63\left(\mathrm{q}, 2 \mathrm{H}, \mathrm{CH}_{2}\right)\right]$ and $38 \%$ benzene $\left[\delta_{\mathrm{H}}: 7.33(\mathrm{q}, 6 \mathrm{H}, \mathrm{ArH})\right.$, based on the ${ }^{1} \mathrm{H}$ and ${ }^{13} \mathrm{C}$ NMR analysis of the residue.

Bibenzyl

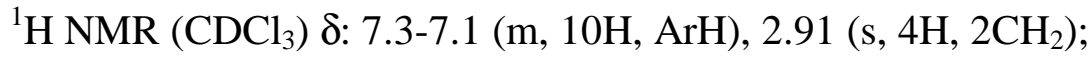

${ }^{13} \mathrm{C}$ NMR $\left(\mathrm{CDCl}_{3}\right) \delta: 141.79,128.9,125.92(\mathrm{ArC}), 37.95\left(\mathrm{CH}_{2}\right)$.

Ethylbenzene

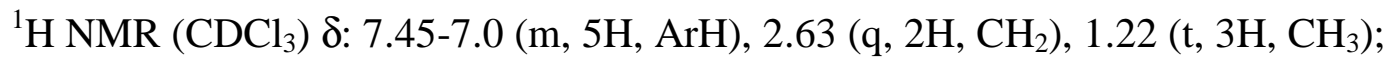

${ }^{13} \mathrm{C} \mathrm{NMR}\left(\mathrm{CDCl}_{3}\right) \delta: 144.24,128.35,127.89,125.65(\mathrm{ArC}), 28.9\left(\mathrm{CH}_{2}\right), 15.6\left(\mathrm{CH}_{3}\right)$.

Benzene

${ }^{1} \mathrm{H} \mathrm{NMR}\left(\mathrm{CDCl}_{3}\right) \delta: 7.33$ (s, 6H, $\left.\mathrm{ArH}\right)$.

${ }^{13} \mathrm{C}$ NMR $\left(\mathrm{CDCl}_{3}\right) \delta: 128.36(\mathrm{ArC})$.

\section{Run 9}

Preparation of $\left(\mathrm{Ph}_{3} \mathrm{CCH}_{2}\right)(\mathrm{Ph}) \mathrm{Zr}(\mathrm{OEt})_{2}$ in THF at low temperature

To finely divided magnesium turnings $(0.03 \mathrm{~g}, 1.2 \mathrm{mmol})$ in $20 \mathrm{~mL}$ THF was slowly added $\mathrm{Ph}_{3} \mathrm{CCH}_{2} \mathrm{Cl}^{2}(0.16 \mathrm{~g}, 0.58 \mathrm{mmol})$ and the resulting reaction mixture was heated at reflux for $12 \mathrm{~h}$. 
After cooling the reaction mixture to room temperature, the clear solution (excluding any unreacted magnesium) was transferred to a white suspension of $\mathrm{Zr}(\mathrm{OEt})_{4}(0.51 \mathrm{~g}, 0.58 \mathrm{mmol})$ in THF (20mL) cooled to $-78^{\circ} \mathrm{C}$. Thereafter to this suspension was slowly added $\mathrm{PhLi}(1.8 \mathrm{M}$ in diethyl ether, $0.32 \mathrm{~mL}, 0.58 \mathrm{mmol}$ ) whereupon the solution turned pale red color on standing at low temperature for $2 \mathrm{~h}$, to give rise to $\left(\mathrm{Ph}_{3} \mathrm{CCH}_{2}\right) \mathrm{PhZr}(\mathrm{OEt})_{2}(0.58 \mathrm{mmol})$, containing $\mathrm{MgCl}(\mathrm{OEt})$ and LiOEt by-products.

\section{The reaction of $\left(\mathrm{Ph}_{3} \mathrm{CCH}_{2}\right)(\mathrm{Ph}) \mathrm{Zr}(\mathrm{OEt})_{2}$ in $\mathrm{THF}$ at reflux}

A suspension of $\left(\mathrm{Ph}_{3} \mathrm{CCH}_{2}\right)(\mathrm{Ph}) \mathrm{Zr}(\mathrm{OEt})_{2}(0.58 \mathrm{mmol})$ in THF was allowed to warm to room temperature in $2 \mathrm{~h}$, stirred at room temperature for $2 \mathrm{~h}$ when the color turned gray. Thereafter the reaction mixture was subjected to $8 \mathrm{~h}$ of reflux when the solution turned light brown before hydrolysis. The organics were extracted with diethyl ether and dried over anhydrous $\mathrm{Na}_{2} \mathrm{SO}_{4}$. The extracts were freed of solvent by using a rotary evaporator to result in isolation of $26 \mathrm{mg}$ of a pasty yellow solid consisting of $19 \%$ triphenylmethane (expected yield $141 \mathrm{mg})\left[\delta_{\mathrm{H}}: 5.49(\mathrm{~s}, 1 \mathrm{H}, \mathrm{CH})\right]$. Other products in this reaction were $21 \%$ toluene $\left[\delta_{\mathrm{H}}: 2.3(\mathrm{~s}, 3 \mathrm{H}\right.$, $\left.\left.\mathrm{CH}_{3}\right)\right], 28 \%$ 1,1,1-triphenylethane $\left[\delta_{\mathrm{H}}: 2.11\left(\mathrm{~s}, 3 \mathrm{H}, \mathrm{CH}_{3}\right)\right]$ and $32 \%$ benzene $\left[\delta_{\mathrm{H}}: 7.33(\mathrm{~s}, 6 \mathrm{H}\right.$,

ArH)], based on the ${ }^{1} \mathrm{H}$ and ${ }^{13} \mathrm{C}$ NMR analysis of the residue. None of the expected 1,1,1,2tetraphenylethane was detected since no signal at 3.9ppm (methylene protons) was noticed in the ${ }^{1} \mathrm{H}$ NMR spectrum.

Triphenylmethane

${ }^{1} \mathrm{H}$ NMR $\left(\mathrm{CDCl}_{3}\right) \delta:$ 7.44-6.94 (m, 15H, ArH), 5.49 (s, 1H, CH);

${ }^{13} \mathrm{C} \mathrm{NMR}\left(\mathrm{CDCl}_{3}\right) \delta: 143.88-126.26(\mathrm{ArC}), 56.75(\mathrm{CH})$.

1,1,1-Triphenylethane

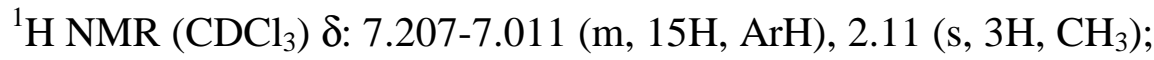




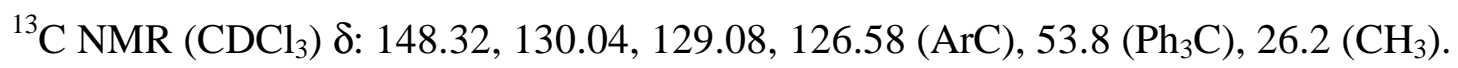

\section{$\underline{\text { Run } 10}$}

The reaction of 1 equivalent of $B u_{2} \mathrm{Zr}(\mathrm{OEt})_{2}$ containing LiOEt with 11 equivalents of 1hexene in hexane at reflux

A suspension of $\mathrm{Bu}_{2} \mathrm{Zr}(\mathrm{OEt})_{2}(2.50 \mathrm{mmol})$ containing LiOEt in hexane was allowed to react with $1.6 \mathrm{~mL}$ (11 equiv.) of freshly distilled 1 -hexene in hexane $(35 \mathrm{~mL})$ at $-78^{\circ} \mathrm{C}$ (Dry Iceacetone bath). The resulting mixture was allowed to warm to room temperature in $2 \mathrm{~h}$. It was stirred at room temperature for $12 \mathrm{~h}$ (development of brown color) and thereafter for $6 \mathrm{~h}$ at reflux. Before being subjected to hydrolysis, volatiles were removed under reduced pressure. The organics were extracted with diethyl ether and dried over anhydrous $\mathrm{Na}_{2} \mathrm{SO}_{4}$. The extracts were freed of solvent to result in the isolation of 380mg of a pale yellow liquid consisting of $88 \%$ of dodecane (expected yield 430mg) and 12\% of decane. Apart from the GC analysis, dodecane and decane were identified by their ${ }^{1} \mathrm{H}$ and ${ }^{13} \mathrm{C}$ NMR signals in the residue. Their respective NMR signals were confirmed by spiking the residue with pure samples.

1-Hexene

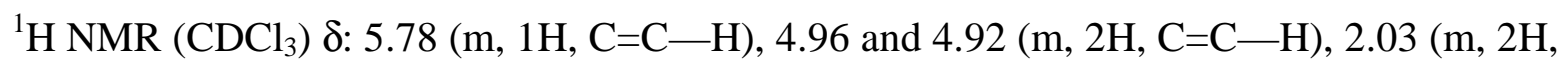
$\left.\mathrm{CH}_{2}\right), 1.50-1.07\left(\mathrm{~m}, 4 \mathrm{H}, 2 \mathrm{CH}_{2}\right), 0.90\left(\mathrm{t}, 3 \mathrm{H}, \mathrm{CH}_{3}\right)$;

${ }^{13} \mathrm{C} \mathrm{NMR}\left(\mathrm{CDCl}_{3}\right)$ \&: 139.05, $114.02(\mathrm{C}=\mathrm{C}), 33.58,31.21,22.24\left(\mathrm{CH}_{2}\right), 13.84\left(\mathrm{CH}_{3}\right)$.

Dodecane

${ }^{1} \mathrm{H} \mathrm{NMR}\left(\mathrm{CDCl}_{3}\right) \delta: 1.27\left(\mathrm{br}, 20 \mathrm{H}, 10 \mathrm{CH}_{2}\right), 0.88\left(\mathrm{t}, 6 \mathrm{H}, 2 \mathrm{CH}_{3}\right)$;

${ }^{13} \mathrm{C}$ NMR $\left(\mathrm{CDCl}_{3}\right) \delta: 32.13,29.87,29.56,22.85\left(\mathrm{CH}_{2}\right), 14.14\left(\mathrm{CH}_{3}\right)$.

Decane 


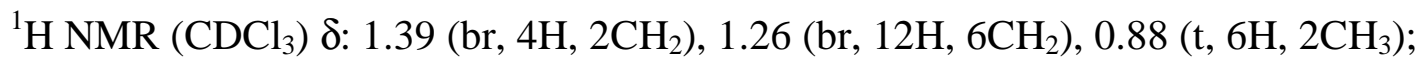

${ }^{13} \mathrm{C} \mathrm{NMR}\left(\mathrm{CDCl}_{3}\right) \delta: 32.16,29.89,29.59,22.88\left(\mathrm{CH}_{2}\right), 14.16\left(\mathrm{CH}_{3}\right)$.

Using $\mathrm{Bu}_{2} \mathrm{Zr}(\mathrm{OEt})_{2}(2.28 \mathrm{mmol})$ in hexane and $1.43 \mathrm{~mL}$ (4equiv.) of 1-octene, $479 \mathrm{mg}$ of a pale yellow liquid was isolated consisting of $93 \%$ hexadecane $\left[\delta_{C}: 32.09\left(C_{3}\right)\right]($ expected yield $516 \mathrm{mg})$ and $7 \%$ dodecane $\left[\delta_{\mathrm{C}}: 32.13\left(\mathrm{C}_{3}\right)\right]$.

Hexadecane

${ }^{1} \mathrm{H} \mathrm{NMR}\left(\mathrm{CDCl}_{3}\right) \delta: 1.26\left(\mathrm{br}, 28 \mathrm{H}, 14 \mathrm{CH}_{2}\right), 0.88\left(\mathrm{br}, 6 \mathrm{H}, 2 \mathrm{CH}_{3}\right)$;

${ }^{13} \mathrm{C} \mathrm{NMR}\left(\mathrm{CDCl}_{3}\right) \delta: 32.09,29.86,29.52,22.82\left(\mathrm{CH}_{2}\right), 14.14\left(\mathrm{CH}_{3}\right)$.

Using $\mathrm{Bu}_{2} \mathrm{Zr}(\mathrm{OEt})_{2}(2.54 \mathrm{mmol})$ in hexane and $1.92 \mathrm{~mL}$ (4equiv.) of 1-decene, $601 \mathrm{mg}$ of a pale yellow liquid was isolated consisting of $84 \%$ icosane $\left[\delta_{C}: 29.47\left(C_{4}\right)\right]($ expected yield $716 \mathrm{mg})$ and $16 \%$ tetradecane $\left[\delta_{C}: 29.53\left(\mathrm{C}_{4}\right)\right]$.

Icosane

${ }^{1} \mathrm{H} \mathrm{NMR}\left(\mathrm{CDCl}_{3}\right) \delta: 1.29\left(\mathrm{br}, 4 \mathrm{H}, 2 \mathrm{CH}_{2}\right), 1.26\left(\mathrm{br}, 36 \mathrm{H}, 18 \mathrm{CH}_{2}\right), 0.879\left(\mathrm{t}, 6 \mathrm{H}, 2 \mathrm{CH}_{3}\right)$;

${ }^{13} \mathrm{C} \mathrm{NMR}\left(\mathrm{CDCl}_{3}\right) \delta: 32.04,29.81,29.47,22.78\left(\mathrm{CH}_{2}\right), 14.14\left(\mathrm{CH}_{3}\right)$.

Tetradecane

${ }^{1} \mathrm{H} \mathrm{NMR}\left(\mathrm{CDCl}_{3}\right) \delta: 1.26\left(\mathrm{br}, 24 \mathrm{H}, 12 \mathrm{CH}_{2}\right), 0.880\left(\mathrm{t}, 6 \mathrm{H}, 2 \mathrm{CH}_{3}\right)$;

${ }^{13} \mathrm{C} \mathrm{NMR}\left(\mathrm{CDCl}_{3}\right) \delta: 32.09,29.86,29.53,22.83\left(\mathrm{CH}_{2}\right), 14.15\left(\mathrm{CH}_{3}\right)$.

\section{$\underline{\text { Run } 11}$}

\section{Preparation of $\mathrm{Me}_{2} \mathrm{Zr}(\mathrm{OEt})_{2}$ in hexane at low temperature}

To a white suspension of $\mathrm{Zr}(\mathrm{OEt})_{4}(0.56 \mathrm{~g}, 2.06 \mathrm{mmol})$ in hexane $(35 \mathrm{~mL})$ cooled to $-78^{\circ} \mathrm{C}$ (Dry Ice-acetone bath) was slowly added $\mathrm{MeMgBr}(1.6 \mathrm{M}$ in diethyl ether, $2.5 \mathrm{~mL}, 4.12 \mathrm{mmol}$ ), whereupon the solution turned off-white color on standing at low temperature for $2 \mathrm{~h}$ to give rise 
to $\mathrm{Me}_{2} \mathrm{Zr}(\mathrm{OEt})_{2}(2.06 \mathrm{mmol})$, containing $\mathrm{MgBr}(\mathrm{OEt})$ by-product.

The reaction of $\mathrm{Me}_{2} \mathrm{Zr}(\mathrm{OEt})_{2}$ in hexane at reflux

A suspension of $\mathrm{Me}_{2} \mathrm{Zr}(\mathrm{OEt})_{2}(2.06 \mathrm{mmol})$ in hexane was allowed to warm to room temperature in $2 \mathrm{~h}$ and stirred at room temperature for $2 \mathrm{~h}$ when the color turned deep brown. Thereafter it was refluxed for $8 \mathrm{~h}$ during which the solution deepened to dark brown before subjecting to iodinolysis by addition of iodine $(0.52 \mathrm{~g}, 4.12 \mathrm{mmol})$. The organics were extracted with diethyl ether and sodium thiosulphate to remove the excess iodine. The extracts were freed of solvent to result in the isolation of $25 \mathrm{mg}$ of pasty brown liquid consisting of $9 \%$ iodoethane (expected yield $321 \mathrm{mg})\left[\delta_{\mathrm{H}}: 3.27\left(\mathrm{q}, 2 \mathrm{H}, \mathrm{CH}_{2}\right)\right]$ and $91 \%$ of iodomethane $\left[\delta_{\mathrm{H}}: 2.26\left(\mathrm{~s}, 3 \mathrm{H}, \mathrm{CH}_{3}\right)\right]$ based on the ${ }^{1} \mathrm{H}$ and ${ }^{13} \mathrm{C}$ NMR analysis of the residue.

Iodoethane

${ }^{1} \mathrm{H} \mathrm{NMR}\left(\mathrm{CDCl}_{3}\right) \delta: 3.27\left(\mathrm{q}, 2 \mathrm{H}, \mathrm{CH}_{2}\right), 1.94\left(\mathrm{t}, 3 \mathrm{H}, \mathrm{CH}_{3}\right)$;

${ }^{13} \mathrm{C} \mathrm{NMR}\left(\mathrm{CDCl}_{3}\right) \delta: 20.59\left(\mathrm{CH}_{3}\right),-1.05\left(\mathrm{CH}_{2}\right)$.

Iodomethane

${ }^{1} \mathrm{H} \mathrm{NMR}\left(\mathrm{CDCl}_{3}\right) \delta: 2.26\left(\mathrm{~s}, 3 \mathrm{H}, \mathrm{CH}_{3}\right)$;

${ }^{13} \mathrm{C} \mathrm{NMR}\left(\mathrm{CDCl}_{3}\right) \delta: 23.30\left(\mathrm{CH}_{3}\right)$.

\section{$\underline{\text { Run } 12}$}

\section{Preparation of $(p \text {-tolyl })_{2} \mathrm{Zr}(\mathrm{OEt})_{2}$ in THF at low temperature}

To finely divided magnesium turnings $(0.27 \mathrm{~g}, 11.1 \mathrm{mmol})$ in $20 \mathrm{~mL}$ THF was slowly added 4-bromotoluene $(0.45 \mathrm{~mL}, 3.68 \mathrm{mmol})$ and the resulting reaction mixture was heated at reflux for $12 \mathrm{~h}$. After cooling the reaction mixture to room temperature, the clear solution (excluding the unreacted magnesium) was carefully transferred to a white suspension of $\mathrm{Zr}(\mathrm{OEt})_{4}$ 
$(0.53 \mathrm{~g}, 1.84 \mathrm{mmol})$ in THF $(20 \mathrm{~mL})$ cooled to $-78^{\circ} \mathrm{C}$, whereupon the solution turned yellow on standing at low temperature for $2 \mathrm{~h}$, to give rise to $(p \text {-tolyl })_{2} \mathrm{Zr}(\mathrm{OEt})_{2}(1.84 \mathrm{mmol})$, containing $\operatorname{MgBr}(\mathrm{OEt})$ as by-product.

\section{The reaction of $(p \text {-tolyl })_{2} \mathrm{Zr}(\mathrm{OEt})_{2}$ in $\mathrm{THF}$ at reflux}

A suspension of ( $p$-tolyl $)_{2} \mathrm{Zr}(\mathrm{OEt})_{2}(1.84 \mathrm{mmol})$ in THF was allowed to warm to room temperature in $2 \mathrm{~h}$ stirred at room temperature for $2 \mathrm{~h}$ and thereafter heated at reflux for $8 \mathrm{~h}$ The solution had turned deep purple prior to hydrolysis. Upon hydrolysis considerable gas evolution $\left(\mathrm{H}_{2}\right)$ was noticed. The organics were extracted with diethyl ether and dried over anhydrous $\mathrm{Na}_{2} \mathrm{SO}_{4}$. The extracts were freed of solvent to result in the isolation of $199 \mathrm{mg}$ of pasty yellow liquid consisting of $59 \%$ of 3,4'-dimethylbiphenyl (expected yield 338mg) [ $\delta_{\mathrm{H}}: 2.29$ (s, 3H, 4'-

$\left.\left.\mathrm{CH}_{3}\right)\right]$ and $41 \%$ of $4,4^{\prime}$-dimethylbiphenyl $\left[\delta_{\mathrm{H}}: 2.36\left(\mathrm{~s}, 6 \mathrm{H}, \mathrm{CH}_{3}\right)\right]$ based on the ${ }^{1} \mathrm{H}$ and ${ }^{13} \mathrm{C}$ NMR analysis of the residue.

3,4'-Dimethylbiphenyl

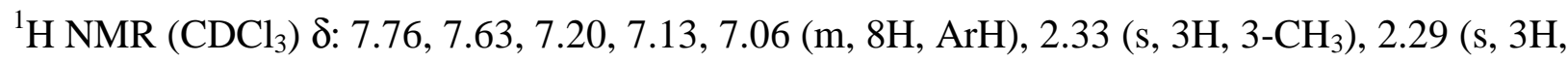
$\left.4^{\prime}-\mathrm{CH}_{3}\right)$;

${ }^{13} \mathrm{C} \mathrm{NMR}\left(\mathrm{CDCl}_{3}\right) \delta: 151.65,138.68,137.25,136.96,134.76,131.25,129.73,129.72,129.34$

(ArC), $22.0\left(3-\mathrm{CH}_{3}\right), 21.08\left(4^{\prime}-\mathrm{CH}_{3}\right)$.

4,4'-Dimethylbiphenyl

${ }^{1} \mathrm{H}$ NMR $\left(\mathrm{CDCl}_{3}\right) \delta: 7.45,7.21(\mathrm{~m}, 8 \mathrm{H}, \mathrm{ArH}), 2.36\left(\mathrm{~s}, 6 \mathrm{H}, \mathrm{CH}_{3}\right)$;

${ }^{13} \mathrm{C} \mathrm{NMR}\left(\mathrm{CDCl}_{3}\right) 138.38,136.69,129.46,126.84(\mathrm{ArC}), 21.07\left(2 \mathrm{CH}_{3}\right)$.

\section{$\underline{\text { Run } 13}$}

Preparation of $\mathrm{Ph}_{2} \mathrm{Zr}(\mathrm{OEt})_{2}$ in THF at low temperature 
To finely divided magnesium turnings $(0.27 \mathrm{~g}, 11.1 \mathrm{mmol})$ in $20 \mathrm{~mL}$ THF was slowly added bromobenzene $(0.39 \mathrm{~mL}, 3.76 \mathrm{mmol})$ and the resulting reaction mixture was heated at reflux for $12 \mathrm{~h}$. After cooling the reaction mixture to room temperature, the clear solution excluding the unreacted magnesium was carefully transferred to a white suspension of $\mathrm{Zr}(\mathrm{OEt})_{4}$ $(0.51 \mathrm{~g}, 1.88 \mathrm{mmol})$ in THF $(20 \mathrm{~mL})$ cooled to $-78^{\circ} \mathrm{C}$ (Dry Ice-acetone bath), whereupon the solution turned grayish on standing at low temperature for $2 \mathrm{~h}$, to give rise to $\mathrm{Ph}_{2} \mathrm{Zr}(\mathrm{OEt})_{2}$ (1.88mmol), containing $\mathrm{MgBr}(\mathrm{OEt})$ as by-product.

\section{The reaction of $\mathrm{Ph}_{2} \mathrm{Zr}(\mathrm{OEt})_{2}$ in $\mathrm{THF}$ at reflux}

A suspension of $\mathrm{Ph}_{2} \mathrm{Zr}(\mathrm{OEt})_{2}(1.88 \mathrm{mmol})$ in $\mathrm{THF}$ was allowed to warm to room temperature in $2 \mathrm{~h}$, stirred at room temperature for $2 \mathrm{~h}$ and thereafter heated at reflux for $8 \mathrm{~h}$, whereupon the solution turned pale yellow before hydrolysis. Before hydrolysis a portion of the reaction mixture was removed for deuteriolysis by $\mathrm{D}_{2} \mathrm{O}$. Upon hydrolysis a trace of gas evolution was noticed. The organics were extracted with diethyl ether and dried over anhydrous $\mathrm{Na}_{2} \mathrm{SO}_{4}$. The extracts were freed of solvent to result in the isolation of $113 \mathrm{mg}$ of pasty yellow solid consisting of $38 \%$ biphenyl (expected yield $289 \mathrm{mg}$ ) [ $\left.\delta_{\mathrm{H}}: 7.59,7.43,7.34(\mathrm{~m}, 10 \mathrm{H}, \mathrm{ArH})\right], 21 \%$ phenol $[\delta: 5.35(\mathrm{~s}, 1 \mathrm{H}, \mathrm{OH})]$ and $40 \%$ of benzene $[\delta: 7.33(\mathrm{~s}, 6 \mathrm{H}, \mathrm{ArH})]$ based on the ${ }^{1} \mathrm{H}$ and ${ }^{13} \mathrm{C}$ NMR analysis of the residue. TLC confirmed the presence of biphenyl in the product mixture. Biphenyl

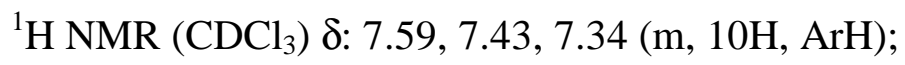

${ }^{13} \mathrm{C}$ NMR $\left(\mathrm{CDCl}_{3}\right) \delta: 140.83,128.35,126.85,126.78(\mathrm{ArC})$.

Phenol

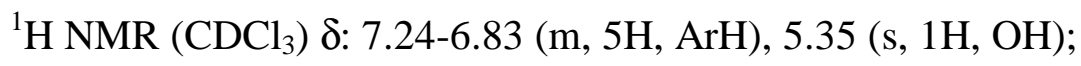

${ }^{13} \mathrm{C}$ NMR $\left(\mathrm{CDCl}_{3}\right) \delta: 155.02,129.79,121.09,115.08(\mathrm{ArC})$. 
The deuteriolytic work-up of a portion of the reaction mixture by $\mathrm{D}_{2} \mathrm{O}$ yielded 2deuteriobiphenyl and deuteriobenzene as corroborated by ${ }^{1} \mathrm{H} \&{ }^{2} \mathrm{H}$ NMR analyses of the residue and comparison with the ${ }^{1} \mathrm{H}$ NMR spectra of authentic samples.

\section{$\underline{\text { Characterization of } \mathrm{Bu}_{2}} \underline{\mathrm{Zr}_{2}(\mathrm{OEt})_{2}} \underline{\text { in THF at low temperature }}$}

\section{Preparation of $\mathrm{Bu}_{2} \mathrm{Zr}(\mathrm{OEt})_{2}$ in THF at low temperature}

To a white suspension of $\mathrm{Zr}(\mathrm{OEt})_{4}(0.67 \mathrm{~g}, 2.46 \mathrm{mmol})$ in $\mathrm{THF}(15 \mathrm{~mL})$ cooled to $-78^{\circ} \mathrm{C}$ (Dry Ice-acetone bath) was slowly added $n$-BuLi (2.5M in hexane, $1.9 \mathrm{~mL}, 4.92 \mathrm{mmol})$, whereupon the solution turned an off-white color on standing at low temperature for $2 \mathrm{~h}$ to give rise to $\mathrm{Bu}_{2} \mathrm{Zr}(\mathrm{OEt})_{2}(2.46 \mathrm{mmol})$ in THF, containing LiOEt as by-product. The volatiles (THF and hexanes) were removed under reduced pressure at $-78^{\circ} \mathrm{C}$ and freshly distilled methylene chloride solvent was added to the dry residue and the ${ }^{1} \mathrm{H}$ NMR spectrum was recorded on the clear supernatant solution at $-60^{\circ} \mathrm{C}$. When this ${ }^{1} \mathrm{H}$ NMR sample tube had stood for some time at room temperature and the spectrum thereafter recorded at $25^{\circ} \mathrm{C}$, all the signals had broadened and the signals for the $n$-butyl groups were greatly diminished in intensity relative to the ethoxy methylene, $-\mathrm{O}-\underline{\mathrm{CH}}_{2}-\mathrm{CH}_{3}$. Evidently, $\mathrm{Bu}_{2}{ }_{2} \mathrm{Zr}(\mathrm{OEt})_{2}$ undergoes significant decomposition above $0^{\circ} \mathrm{C}$.

${ }^{1} \mathrm{H} \mathrm{NMR}\left(\mathrm{CDCl}_{3}\right) \delta: 3.88\left(\mathrm{t}, 4 \mathrm{H}, 2 \mathrm{OCH}_{2}\right), 1.268\left(\mathrm{~m}, 18 \mathrm{H}, 3 \mathrm{CH}_{2}, 2 \mathrm{CH}_{3}\right) 0.88\left(\mathrm{t}, 6 \mathrm{H}, 2 \mathrm{CH}_{3}\right)$. Integration of the peaks at $0.88 \mathrm{ppm}$ and $1.268 \mathrm{ppm}$ produced an observed ratio of $1: 2.9$, consistent with the expected ratio of $6: 18$. The peak at 3.88ppm when compared with other peaks produced a slightly lower integral value than expected. Lack of broad peaks are consistent with a monomeric $\mathrm{Bu}_{2} \mathrm{Zr}(\mathrm{OEt})_{2}$. Absence of any signal at 4.8-4.9ppm rules out the presence of any 1butene in the reaction mixture. No signal was detected in the upfield region ( -5 to $-15 \mathrm{ppm})$, consistent with the absence of any agostic $\mathrm{C} \cdots \mathrm{H} \cdots \mathrm{Zr}$ interaction. The ${ }^{1} \mathrm{H}$ NMR of $\mathrm{Zr}(\mathrm{OEt})_{4}$ 
produced signals at $3.734\left(\mathrm{q}, \mathrm{CH}_{2}\right)$ and $1.236\left(\mathrm{t}, \mathrm{CH}_{3}\right)$.

\section{Characterization of $\mathrm{Bu}_{2} \underline{\mathrm{ZrCl}}_{2} \underline{\text { in THF at low temperature }}$}

\section{Preparation of $\mathrm{Bu}_{2} \mathrm{ZrCl}_{2}$ in THF at low temperature}

To a white suspension of $\mathrm{ZrCl}_{4}(0.77 \mathrm{~g}, 3.30 \mathrm{mmol})$ in $\mathrm{THF}(15 \mathrm{~mL})$ cooled to $-78^{\circ} \mathrm{C}$ (Dry Ice-acetone bath) was slowly added $n$-BuLi $(2.5 \mathrm{M}$ in hexane, $2.6 \mathrm{~mL}, 6.6 \mathrm{mmol})$, whereupon the solution turned pale yellow on standing at low temperature for $2 \mathrm{~h}$ to give rise to $\mathrm{Bu}_{2} \mathrm{ZrCl}_{2}$ (3.30mmol) in THF, containing $\mathrm{LiCl}$ by-product. THF solvent was pumped off to remove any coordinated THF from $\mathrm{Bu}_{2} \mathrm{ZrCl}_{2}$, and freshly distilled methylene chloride solvent was added to the dry residue and the ${ }^{1} \mathrm{H}$ NMR spectrum was recorded on the sample at $-60^{\circ} \mathrm{C}$.

${ }^{1} \mathrm{H} \mathrm{NMR}\left(\mathrm{CDCl}_{3}\right) \delta: 1.268\left(\mathrm{~m}, 12 \mathrm{H}, 3 \mathrm{CH}_{2}\right) 0.882\left(\mathrm{t}, 6 \mathrm{H}, 2 \mathrm{CH}_{3}\right)$.

Integration of the peaks at $0.882 \mathrm{ppm}$ and $1.268 \mathrm{ppm}$ gave a ratio of $1: 1.8$, consistent with the expected ratio of 6:12. Lack of broad peaks is consistent with the presence of the monomer free of any association. Absence of any signal at 4.8-4.9ppm rules out the presence of any 1butene in the reaction mixture. No signal was detected in the upfield region $(-5$ to $-15 \mathrm{ppm})$ $\mathrm{C}-\mathrm{H}-\mathrm{M}$ consistent with the absence of any agostic $\mathrm{C} \cdots \mathrm{H} \cdots \mathrm{M}$ interaction.

\section{$\underline{\text { References and Notes }}$}

1. Eisch, J.J. Organometallic Syntheses, vol. 2, Academic Press, New York, pp. 1-52.

2. Eisch, J.J.; Kovacs, C.A.; Chobe, P. J. Org. Chem. 1989, 54, 1275. 